\title{
Secrets Revealed: \\ How Magicians Protect Intellectual Property Without Law
}

\author{
By Jacob Loshin \\ J.D., 2007, Yale Law School \\ $7 / 25 / 07$ \\ --WORKING DRAFT--
}

Substantially revised final version to be published in LAW AND MAGIC: A Collection of Essays (Durham, NC: Carolina Academic Press, 2008)

Please send any reactions or comments to: Jacob.Loshin@gmail.com

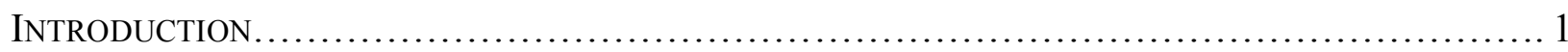

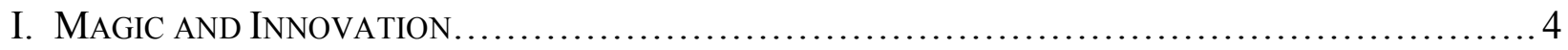

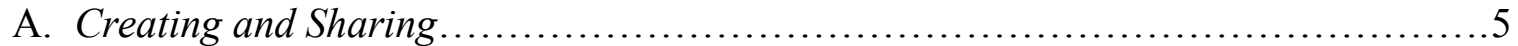

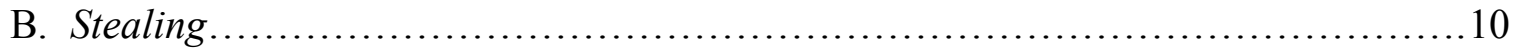

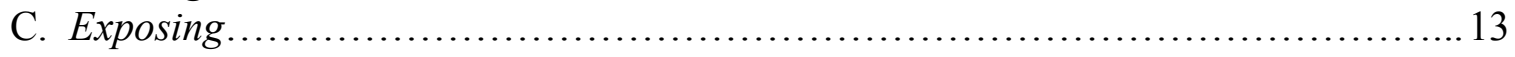

II. The Limits of Intellectual Property Law ........................................ 18

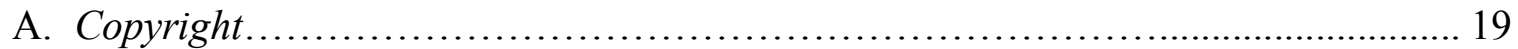

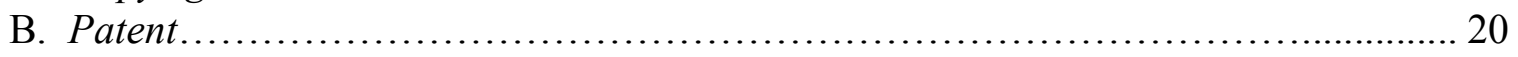

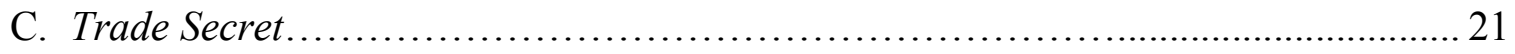

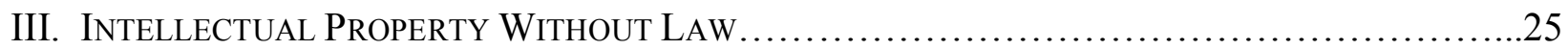

A. Controlling Access: Magic as a Common-Pool Resource............................22

B. Attribution, Use, and Exposure Norms..................................... 28

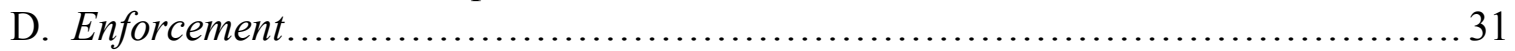

IV. Conclusion: Lessons for Intellectual Property Theory .......................................34 


\section{INTRODUCTION}

For centuries, magicians have sought to tame the laws of nature. They have made pebbles jump from place to place, pulled rabbits from hats, made canes dance, turned doves into handkerchiefs, plucked cards and coins from thin air, levitated their assistants in midair, sawed ladies in half, and made nearly everything disappear-from coins to elephants to the Statue of Liberty. And all of this with the effortlessness of a waved wand or a muttered abracadabra. Of course, this enchanting control over the laws of nature has usually also been presented with a knowing wink of the eye. These magicians are not demigods, but rather performers and entertainers who we ask to suspend our disbelief by way of illusion, artifice, and prestidigitation. "[I]t is the very trickery that pleases me," Seneca wrote long ago. "But show me how the trick is done, and I have lost my interest therein." Hence, the ancient ability of magicians to control the world around them, for our amusement, depends on their ability to control the ideas and methods of their art— the hidden "trickery" that makes magic possible.

Yet, despite the overwhelming importance of this intellectual property to the magic community, the law of intellectual property ("IP") offers magicians very little assistance. Magicians labor in what has come to be known as IP's "negative space," an area of creative endeavor to which traditional IP protections do not apply. ${ }^{2}$ Legal scholars have much to learn from such negative spaces, since the dynamics of low-IP industries can inform views about the nature and necessity of IP protections in more frequently discussed high-IP industries. So far, scholars have begun to glean insights from the fashion industry and the culinary industry, two

\footnotetext{
${ }^{1}$ Lucius Annaeus Seneca, Moral Epistles, at XLV (Richard M. Gummere trans., Loeb Classical Library ed., 1917).

${ }^{2}$ Kal Raustiala \& Christopher Sprigman, The Piracy Paradox: Innovation and Intellectual Property in Fashion Design, 92 VA. L. REV. 1687, 1762-65 (2006).
} 
areas where innovation surprisingly seems to thrive in the absence of strong IP protection. ${ }^{3}$ This paper furthers the effort by studying the unique dynamics of another negative space- the community of professional and amateur performing magicians. Although a few legal scholars have noted with curiosity the lack of IP in the magic industry, ${ }^{4}$ no scholar has yet examined IP's workings there. Hence, for the first time, this paper pulls back the curtain, a bit, on the world of magic.

But not too much. You will not find here the secrets to how magicians perform their many feats of mystery. Sorry, tough luck. This paper will, however, reveal the secret to a different sort of mystery. The standard economic theory of intellectual property holds that law must delimit and enforce property rights in order to promote innovation. Without such legal protection, creators lack an incentive to invest in future innovation. After all, why develop and invest in an idea if you know that it can be used by a competitor without legal consequence? If intellectual property law does not protect ideas, the standard theory thus predicts sluggish innovation. Yet, while magicians have few legal rights to their intellectual property, innovation nevertheless seems to thrive.

This mystery has been found in IP's other negative spaces as well. In fashion, for instance, two scholars have observed the mystery and explained it by arguing that top designers actually want their designs to be copied so that high-fashion designers can secure the benefits of

\footnotetext{
${ }^{3}$ See id. at 1769-74 (discussing the fashion industry and listing other potential negative spaces for further study); Christopher J. Buccafusco, On the Legal Consequences of Sauces: Should Thomas Keller's Recipes Be Per Se Copyrightable?, 24 CARDOZO ARTS \& ENT. L.J. 1121 (2007); Emmanuelle Fauchart \& Eric A. von Hippel, NormBased Intellectual Property Systems: The Case of French Chefs, MIT Sloan Research Paper No. 4576-06, available at http://papers.ssrn.com/sol3/papers.cfm?abstract_id=881781.

${ }^{4}$ See Raustiala \& Sprigman, supra note 2, at $177 \overline{4}$ ("Magic tricks . . . are potentially copyrightable subject matter, but ... we do not see copyright lawsuits."); Michael A. Carrier, Cabining Intellectual Property Through a Property Paradigm, 54 DuKE L.J. 1, 36-37 (2004) ("Further questioning the need for copyright, many forms of creative expression - such as fashions, new words and slogans, jokes and magic tricks, and the food industry-have flourished in the absence of protection.").
} 
"induced obsolescence." ${ }^{5}$ As the designs trickle down fashion's status pyramid, they become passé and create demand for new high-fashion designs from the top, fueling a cycle of continuous demand. Some might seize on this explanation as disproof of the traditional economic theory of IP, illustrating how innovation does not need intellectual property after all. Yet, this paper discovers that the secret to the mystery is different for magicians than it is for fashionistas. The magicians' secret lies not in the desire for low-IP, but rather in an alternative to it. This paper illustrates how the magic community has developed a unique set of informal norms and sanctions for violators, which protect intellectual property in the absence of law. Hence, in the magic community, innovation does in fact need intellectual property. But it does not necessarily need intellectual property law. ${ }^{6}$

This paper proceeds in four parts. Part I offers an introduction to the world of magic and outlines the innovation dynamics at play in the magic community. Part II then explores the application of intellectual property law to magic, illustrating how copyright, patent, and trade secret law afford precious little protection for magicians' most valuable intellectual property. Part III explains the norm-based intellectual property system that governs the magic community in the absence of law. Finally, Part IV discusses what lessons IP scholars might draw from this case study of the magic community, stressing the idiosyncratic nature of IP's negative spaces and the promising but fragile nature of norm-based alternatives to IP law.

\footnotetext{
${ }^{5}$ Raustiala \& Sprigman, supra note 2, at 1718-21.

${ }^{6}$ Robert Ellickson pioneered this view in his study of the informal norms that govern disputes among cattle ranchers in Shasta County, Robert C. Ellickson, Order Without Law: How Neighbors Settle Disputes (1991), and other scholars have since discovered the powerful influence of social norms in a variety of other property-law contexts. See, e.g., JAmes M. Acheson, The Lobster GAngs of MAIne (1988); Lisa Bernstein, Opting out of the Legal System: Extralegal Contractual Relations in the Diamond Industry, 21 J. LEGAL STUDIES 115 (1992). A few scholars have begun to identify informal norms in the context of intellectual property. See Fauchart \& von Hippel, supra note 3 (observing a norm-based intellectual property system among French chefs); Robert Merges, Property Rights and the Commons: The Case of Scientific Research, 13 Soc. PHIL. \& POL'Y 145 (1996) (observing the influence of norms on scientific researchers).
} 


\section{Magic And Innovation}

For as long as man has lived within the constraints imposed upon him by worldly existence, magicians have satisfied a yearning to explain those constraints, and then to break free of them. Indeed, magic has been called the "second-oldest profession," and the yearning it satisfies may be nearly as strong as that of its predecessor. Magic has its roots in the earliest tribal societies, where it began as a supernatural practice invoked by religious leaders, mystics, medicine men, and the like. Gradually, this supernatural magic gave way to entertainment magic, or "secular magic," as it has been called. ${ }^{8}$

All along, magic has struggled for respectability even as it has garnered constant fascination. Secular magic has been deemed at once trivial and threatening. ${ }^{9}$ Alciphron, an Athenian, recalled being "almost speechless" as he watched a magician display several white pebbles. "These he placed one by one under the dishes, and then, I do not know how, made them appear all together under one."11 But Alciphron resisted offering the magician his hospitality, worrying, "We should never be able to catch him in his tricks, and he would steal everything I had, and strip my farm of all it contains." ${ }^{\prime 2}$ Magic was no way to make friends. And for much of its history, magic's practitioners - supernatural and secular alike - have been loners, outcasts, and miscreants.

\footnotetext{
${ }^{7}$ JAMES RANDI, CONJURING Xi (1992).

${ }^{8}$ Simon During, Modern Enchantments: The Cultural Power of Secular Magic 1 (2002).

${ }^{9}$ One scholar has argued that this triviality is itself a non-trivial intellectual source of the Enlightenment. He observes that "secular magic has been a powerful agent in the formation of modern culture precisely because it is trivial." Id. at 2. As magic became "self-consciously illusory," it revealed the distinction between superstitious appearances and actual reality. Id. at 27. The possibility of "illusions understood as illusions" highlights the need to separate truth from superstition. $I d$. at 2 .

${ }^{10}$ See Milbourne Christopher \& Maurine Christopher, The Illustrated History of Magic 10 (1996).

${ }^{11} \mathrm{Id}$.

${ }^{12} I d$.
} 
In time, however, magic evolved from the work of an atomistic collection of loners into the craft of a more cohesive industry. This Part takes a brief and selective tour through the history of magic, illustrating the innovation dynamics at work in the magic industry—how magic's mysteries and illusions originate and evolve over time. We will observe how magicians benefit from sharing their ideas, but also how they are threatened by the misuse of them. We will see how the magic industry's "innovation ecology" is animated by the need to balance the benefits of sharing against the risks of stealing and exposure. ${ }^{13}$ This comprises the backdrop against which intellectual property rights can be assessed.

\section{A. Creating and Sharing}

By the late nineteenth century, entertainment magic had come into full bloom as a theatrical art. In these vaudeville days, which stretched into the early twentieth century, magicians brought large crowds to theatres and music halls on multiple continents. From New York's colossal Hippodrome Theatre to England's St. George's Hall and Royal Polytechnic, vaudeville-era magicians vied to present the next "world's greatest illusion." In this time before television and the internet, traveling magicians would crisscross the globe, bringing their shows to small towns and big cities alike. There was considerable money to be earned, fame to be achieved, and social respect to be gained. And this heady time would become magic's greatest period of creativity and innovation. Although considerable advantage accrued to those magicians who invented new ideas and performed them exclusively, this period of innovation also coincided with the rise of institutions that enabled magicians to share their ideas with one another. And such institutions remain in place today.

\footnotetext{
${ }^{13}$ Raustiala \& Sprigman, supra note 2, at 1762.
} 
A slew of magicians-only magazines emerged: The Sphinx, The Wizard, The Magic Circular, Conjurer's Monthly, and Mahatma. Today, these have been replaced by three principal trade journals, Genii, Magic, and The Linking Ring. In these magazines, magicians publish ideas for new tricks, make adaptations to old ones, and share anecdotes, advice, and other information about their craft. The vaudeville era also saw the rise of magic books. The books were often written by well-known magicians, who would share the tricks that they had invented and refined over the course of their performing careers. Today this practice continues, and most of the books are issued by specialty publishing houses that cater to the magic community. The heady vaudeville days also gave rise to magic manufacturers, dealers, and retail "emporiums," which sold specialty apparatus and "gimmicks" to magicians for use in their performances. Today, a "magic shop" can be found in almost every major city, and many more sell their wares through the mail and online.

Finally, the vaudeville era spawned organizations and networks that connected magicians with each other. In 1902, the Society of American Magicians was born, and Harry Houdini became one of its first presidents. In 1905, London's Magic Circle formed, and the International Brotherhood of Magicians followed soon after. Today, these organizations support a vibrant network of magicians who come together frequently for large conventions, exhibitions, practicesessions, and lectures. More informal gatherings and clubs connect magicians as well. And the organizations and gatherings vary in their exclusivity. Not just anyone can join Hollywood's Magic Castle club or attend Eugene Burger's Mystery School, and only a select few get invited to Fechter's Finger Flicking Frolic. ${ }^{14}$

\footnotetext{
${ }^{14}$ Fechter's Finger Flicking Frolic (known as "4F") is an elite convention for the world's most gifted sleight-of-hand artists. Here's what it takes to snag an invite: You must have two sponsors who have attended a $4 \mathrm{~F}$ convention before and are willing to stick their necks out for you. ... First-timers are expected to perform and you must do at least one trick .... After you
} 
By way of trade journals, books, dealers, and organizations, ideas flow freely and actively within the magic community. Often, an innovative magician will keep a new idea to herself as part of her performing repertoire, sharing the secret with the wider community of magicians after enjoying its exclusive use for a while. Magicians seek out the latest trick or clever new technique to add to their acts. The better magicians try to improve the new tricks they learn, and adapt them to fit their own performing style. Within the magic community, a certain prestige and renown attaches to those innovative magicians who share clever new inventions with their magic brethren. Indeed, among magicians, Jim Steinmeyer and John Gaughan tend to garner more respect and admiration than household name David Copperfield. The former invent and design illusions which have been performed by the latter. Many seasoned magicians take pride in sharing their modus operandi with the next generation of magicians. Renowned nineteenth century French magician Jean Eugene Robert-Houdin, in one of the best and most influential magic books ever written, dedicated his work "to my future brethren in the magic art." ${ }^{, 15}$ He added, "May the instructions contained in this book be as profitable to them as the composition of those instructions has been pleasant to me."16

This evolutionary process of invention, sharing, and gradual refinement has improved many tricks over ensuing decades and even centuries. Indeed, some magicians believe that genuinely original inventions remain quite rare. Nevil Maskelyne, one of magic's greatest—and ironically, most innovative — old masters, claimed, "The difficulty of producing a new magical

become a regular attendee you MUST be ready to perform at every convention if you are asked within 5-6 minutes. ... Your first time attendance does not guarantee you a place for the next year's convention. You are on probation the first year and if you receive an invitation for the next year it means you were accepted by your peers for future $4 \mathrm{Fs}$.

Obie O'Brien, An Open Letter from Obie Regarding the 4F, available at http://www.ffffmagic.com/stories/openletter.html.

15 Jean Eugene Robert-Houdin, Les Secrets de la Magie et de la Prestidigitation ("The Secrets of Conjuring and Magic") (1868), translated and reprinted in EssENTIAL RoBERT-HOUDIN, at 21 (Todd Karr ed., 2006).

${ }^{16} I d$. 
effect is about equivalent to that of inventing a new proposition in Euclid." ${ }^{17}$ This was most certainly an overstatement, but it did capture a certain truth. Magicians have been performing the same sorts of effects - causing things to float, appear, vanish, transport, or transmute-for generations. And their methods have often relied on the same basic principles of visual, physical, and psychological artifice. Yet, within this broad frame, magic has seen a considerable amount of innovation. Much like innovation in scientific research, innovation in magic is often cumulative. ${ }^{18}$ An old effect will be given a new method, a technique will be made simpler and less detectable, or a an old method will be improved by a psychological subtlety in a new presentation.

Some of today's best known tricks have resulted from this long, accretive process. Take, for instance, the "cups and balls" trick, which is one of magic's oldest and was the trick that so astounded Alciphron the Athenian in ancient Greece. The trick is deceptively simple. A magician displays a set of three cups and three balls. When covered by the cups, the balls appear, disappear, multiply, and jump mysteriously from cup to cup. The finale usually involves making something entirely improbable appear under the cups - from larger balls to live baby chicks, and beyond. Once one knows the various methods, the trick is fairly easy to perform poorly but extremely difficult to perform well. Although the basic trick has been around for centuries, there are as many versions of it as there are magicians who perform it. Indeed, mastering and adapting the cups and balls trick has become something of a rite of passage for aspiring sleight-of-hand artists.

The famous "Metamorphosis" illusion offers a second example of gradual innovation, this time on a larger scale. Nineteenth century magician John Nevil Maskelyne invented

${ }^{17}$ Nevil Maskelyne \& David Devant, Our Magic: The Art in Magic, The Theory of Magic, The Practice OF MAGIC 67 (1911).

${ }^{18}$ See generally Merges, supra note 6. 
Metamorphosis, but Harry Houdini popularized it. Houdini would be tied up, put inside a cloth sack, and locked inside a heavy trunk. His wife, Bess, would then pull a curtain around the trunk. She would walk behind the curtain and clap her hands three times, at which point the curtain would fall to reveal Houdini standing where his wife had been. Houdini unlocked the trunk and revealed his wife to be tied up inside. This was an impressive illusion, but it was nothing compared to the jaw-dropping version of the same trick performed today by the magical duo known as the Pendragons. Where Houdini took at least three seconds to metamorphose, the Pendragons do it in a millisecond. Literally. Charlotte Pendragon stands on top of the trunk and throws a drape in front of her. Before the drape can fall a few feet toward the floor, she has already transformed into her husband, Jonathan. ${ }^{19}$ Hence, over time what began as a pleasing curiosity in Houdini's hands became a downright miracle in the hands of the Pendragons.

Of course, not all magic secrets are created equal. Secrets and ideas flow freely and actively among magicians, but sharing tends to occur on different levels. Magician Jim Steinmeyer explains it well:

To really understand magic, you need to nudge past the tyros at the magic shop and sidle up to the old professionals standing in the corner, who aren't interested in the five-dollar plastic envelopes stuffed with instructions, but are whispering in a weird sort of shorthand - the names of past masters, the precise moment they chose to 'accidentally' drop a silk handkerchief on the stage and pick it up, or the particular bend in their thumb as they cut a deck of cards in preparation for a shuffle. ${ }^{20}$

Although surely an oversimplification, we can view the sharing of secrets as occurring along three distinct channels. First there are the cheap plastic tricks sold in magic and novelty shops,

\footnotetext{
${ }^{19}$ To watch the Pendragons perform this trick, you can download a video at http://www.thependragons.net.

20 Jim Steinmeyer, Hiding the Elephant: How Magicians InVented the Impossible and Learned to DISAPPEAR, at xix (2003).
} 
included in children's "magic sets," or taught in short books with titles like "Ten Easy Card Tricks to Amuse Your Friends." These tricks tend to be easy to find, easy to do, and not very good. We might label this "popular magic." Second is the large mass of secrets and routines shared among serious magicians in books and lectures, on instructional videos, at conventions, and in magic clubs. These tend to be magicians' bread and butter, and many of the tricks have been shared among magicians for ages, often improved upon with each successive generation. They tend to be used by professionals, as well as learned and practiced by amateur enthusiasts. These secrets could be labeled "common magic." Finally, the third channel is more informal, and it involves select sharing of the really good and innovative stuff among the magic world's top performers. We might call this "proprietary magic." These three kinds of secrets fall along a bell curve distribution, with common magic predominating in the middle and popular and proprietary magic making up a smaller part of the whole on either end.

\section{B. Stealing}

Although much innovation has been spurred along through sharing, magicians take a less charitable view of those who steal other magicians' ideas without permission. And from time to time, stealing has caused some high-profile spats. In the late 1870s, magician Buatier deKolta performed a memorable trick on the stages of Paris whereby he produced a copious number of paper flowers from inside a previously empty piece of rolled up paper. On one night at the Eden Theatre, a draft of wind carried some of the paper flowers onto the floor in front of the stage. Seizing the opportunity, a magician in the audience picked up a flower and rushed out of the theatre. The flower's ingenious design circulated among magicians, and many others were soon

\section{WORKING DRAFT}


performing deKolta's signature trick. Today, any magician can purchase "deKolta flowers" for a few bucks. ${ }^{21}$

Yet, perhaps the most infamous instance of espionage and skullduggery in the magic community surrounds one of magic's most well-known illusions: the "floating lady." The levitation trick had been around for ages, but Maskelyne invented a brilliantly revolutionary method of doing it. The lady would lay down in the middle of the stage, away from the curtains and illuminated in bright light. Slowly she would levitate high above the stage, and Maskelyne would pass a hoop around her to show that nothing was holding her up. Maskelyne's levitation badly fooled all of the magicians who watched it. Jim Steinmeyer has called it the "closest thing magicians have ever had to the Holy Grail." ${ }^{22}$ Describing his experience watching the levitation, famous Dutch magician David Tobias Bamberg admitted, "[W]hat I saw today is beyond any comprehension." He added, "I haven't one percent of an idea how that could be done!"23 But Harry Kellar, a well-known American magician, matched Bamberg's surprise with equal parts of jealousy. Kellar attended many of Maskelyne's shows, and sat in different parts of the audience in an effort to discover Maskelyne's secret, all to no avail. Finally, Kellar sat in the very front of the theatre and rushed up onto the stage during the levitation. He glimpsed the mechanism from the stage, and then quickly fled the theatre.

Unfortunately for Kellar, however, the glimpse was not enough. He saw how the illusion worked, but he did not learn enough to be able to reproduce it. Maskelyne knew this and figured that Kellar would try to learn the secret from one of Maskelyne's assistants. So Maskelyne recruited his own double-agent and coached him to supply Kellar with fake drawings of how the illusion worked. Yet, Kellar got the better of Maskelyne by recruiting a different spy, one of

${ }^{21}$ This story was recounted by Jim Steinmeyer. See id. at 161-62.

${ }^{22} I d$. at 170 .

${ }^{23}$ Id. at 165 . 
Maskelyne's most trusted assistants. Kellar enticed the assistant, an aspiring grand illusionist himself, by promising him a career as Kellar's successor in America. The two conspired for over a year while the treacherous assistant continued to work for Maskelyne and while Kellar clandestinely built the apparatus. The assistant soon departed for America, and Kellar began to show off the pilfered illusion in January of 1904. The program for Kellar's show bragged that the levitation was the "sensational marvel of the twentieth century and the crowning achievement of Mr. Kellar's career. ${ }^{, 24}$ And truth be told, it was in fact both of those things. Maskelyne soon learned of the theft, but the anger gave way to a worry that Kellar might have managed to improve the illusion. Thus, Maskelyne paid someone in America to sneak backstage and photograph Kellar's apparatus so that Maskelyne could study it. Finally, in a last ironic twist, magician Charles Carter stole Kellar's stolen secret yet again, and incorporated it into his own show to Kellar's dismay.

Despite the intrigue of the levitation affair, it may be the exception that proved the rule. Such grand thefts happen from time to time, but they remain fairly uncommon. Magicians tend to find them regrettable, but not devastating. One reason for this is that magicians consider their tricks to be only a part of their craft, the other part being performance and showmanship. RobertHoudin famously instructed that a magician at his best is not a trickster know-it-all, but rather "an actor playing the part of a magician." 25 David Devant and Nevil Maskelyne echoed the sentiment, observing, "Tricks and dodges are of comparatively small importance in the art of magic." ${ }^{26}$ And in Jim Steinmeyer's words, magic has always been "part science and part showmanship. ${ }^{27}$

\footnotetext{
${ }^{24} I d$. at 176.

${ }^{25}$ ROBERT-HOUDIN, supra note 15 , at 39.

${ }^{26}$ MASKELYNE \& DEVANT, supra note 17.

${ }^{27}$ STEINMEYER, supra note 20 , at $\mathrm{xx}$-xxi.
} 
Hence, magicians tend to treat the ripping off of someone's "act" more seriously than they treat the mere pilfering of a secret. The latest high-profile instance of this sort of stealing occurred when magical upstart Eric Walton copied the work of highly-renowned magician Ricky Jay. Not only did Walton perform an old trick Jay had previously resurrected from the annals of magic history, but Walton mimicked the distinctive style of Jay's act—a charmingly pedantic routine, where Jay uses esoteric words and presents himself as a kind of mad professorial genius. After watching Walton's show, Jay expressed his displeasure to the New York Times, "I paid for a ticket and I sat through the show, and I would very much like my money and my material back. ${ }^{28}$ Teller, of the magical duo Penn \& Teller, joined Ricky Jay in ridiculing the imposter. Teller dismissed Walton backhandedly, explaining, "magicians are not unique in their absence of creativity. ${ }^{29}$

\section{Exposing}

Despite the potential for stealing, however, the biggest threat to magicians' intellectual property lies elsewhere-in the exposure of magic secrets to the lay public. Magicians have endured a handful of memorable instances of large-scale exposure over the years. Ironically, one of the first and most widely disseminated exposures was intentionally issued by a friend of magic, and was perpetrated for magic's benefit. In 1584, Reginald Scot published The Discoverie of Witchcraft, a book which revealed various magic secrets including the above-mentioned "cups and balls" trick. Yet, Scot's book aimed to dissuade religious authorities from persecuting magicians, by rebutting allegations that magicians were witches. ${ }^{30}$

\footnotetext{
${ }^{28}$ Campbell Robertson, Dueling Magicians: Whose Trick Is It Anyway?, N.Y. TIMES, Sep. 27, 2006.

${ }^{29} \mathrm{Id}$.

${ }^{30}$ See CHRISTOPHER \& CHRISTOPHER, supra note 10, at 23-24.
} 
Later exposures, however, tended to stem from more nefarious purposes. Giovanni Giuseppe Pinetti, the preeminent magician of the late eighteenth century, found himself a victim of exposure when he took his act to France. Pinetti impressed the King in a private performance and attracted sold-out crowds to Paris theatres until magician and lawyer Henri Decremps published a best-selling expose of Pinetti. ${ }^{31}$ The book, La Magic Blanche Devoilee, purported to lay bare all of Pinetti's secrets. ${ }^{32}$ Although Decremps' explanations were often erroneous, he nevertheless damaged Pinetti's reputation and ruined his material. Legend has it that Pinetti got his revenge with a bold ruse befitting a clever magician. Pinetti supposedly hired a shabbylooking vagabond to attend his show and pretend to be Decremps. The vagabond was instructed to stand up during Pinetti's show, announce himself as Decremps, and harass Pinetti from the audience. Pinetti then proceeded to calmly endure the vagabond's ravings, toss him a few coins, and dismiss the pitiful character from the theatre, word of the apparent humiliation spreading far and wide.

More recently, in what one observer has called "the mother of all exposures," R.J. Reynolds exposed thirty-nine classic tricks as part of a massive advertising campaign in 1933 to sell Camel cigarettes. ${ }^{33}$ The full-color ads, which ran in 1,200 American newspapers for eight months, peddled cigarettes with a catchy slogan: "It's fun to be fooled . . . It's more fun to know." ${ }^{34}$ It remains unclear just what this had to do with cigarettes; one thinks it may be better for R.J. Reynolds that its customers didn't know many things about its product. In any case, the ads gave a description of each of the thirty-nine illusions followed by a short explanation of how

\footnotetext{
${ }^{31}$ See id. at $86-87$.

${ }^{32}$ Henri Decremps, La Magic Blanche Devoilee ("Natural Magic Disclosed") (1784).

${ }^{33}$ Mike Caveney, The Camel Cigarette Wars: 60 Years Later, MAGIC MAGAZINE 28, at 28 (Apr. 1994).

${ }^{34} I d$.
} 
each trick was done. Some of the ads offered explanations that bordered on the absurd. Here's the description of the method behind one exposed levitation:

[T]he girl wears a concealed harness, which ends in a socket between her shoulder blades. This is attached to a piston below the stage. The piston is pushed up from below, causing her to rise in the air. The piston is invisible because it is covered with mirrors which reflect surrounding draperies $\ldots{ }^{35}$

The brilliant Maskelyne-Kellar levitation this was not. And woe to the person who actually tried to perform this exotic miracle. ${ }^{36}$ Many of the exposures, however, were more damaging, and even the false exposures served to devalue magicians' work. You need to know something about mirrors to truly appreciate why the above method wouldn't work, and a layman may well thus dismiss everything he sees on stage as "done with mirrors."

The most recent major exposure occurred in the late 1990s, when someone posing as a "masked magician" revealed a number of fairly serious illusions in a series of four prime-time Fox television specials. The first special, titled "Breaking the Magician's Code: Magic's Secrets Finally Revealed," broke ratings records with twenty-four million viewers, more than any game of the prior year's baseball World Series. ${ }^{37}$ Magicians were outraged. One of the specials revealed the secret to the Metamorphosis illusion, and Jonathan Pendragon summed up magicians' sentiments well: “It's like destroying Santa Claus or the Easter Bunny. I find these specials pathetic. It's easy to destroy. It's not easy to create." 38 If you do not know the secret to Metamorphosis, the Pendragons' split-second performance of it is genuinely a thing of beauty. If you do know the basic principle, however, the trick becomes merely an impressive technical feat,

\footnotetext{
${ }^{35} I d$. at 31 .

${ }^{36}$ One magician downplayed the exposures to his audiences with a colorful analogy, quipping, "try reading a few boxing lessons and then punching a big man in the nose." Id. at 33.

${ }^{37}$ Paul Brownfield, What's This Guy Got Up His Sleeve?, L.A. TIMES, Mar. 3, 1998.

${ }^{38}$ Greg Braxton, Magicians Wish Fox Special Would Vanish, L.A. TIMES, May 1, 1998.
} 
or at best a physical puzzle. The Fox specials profited from the cheap thrill of the secret, but they destroyed the ultimately more satisfying thrill of the mystery. They also threatened the livelihoods of many magicians who performed the exposed illusions. These performers invested money to built the illusions and time to practice and perfect them. Fox and the Masked Magician made money by tearing them down. As one angry magician put it, with a memorable image, “they're peeing in everybody's corn flakes.",39

In the wake of all of these past exposures, magicians have not always agreed about the damage exposure does. Some magicians find it to be a minor annoyance, but not a grave threat to the magic community. Others, in what is undoubtedly a majority view, vigorously oppose it. The case for apathy tends to rely on two oft-repeated arguments. The first argument taps into a certain brand of magicians' machismo. If something gets exposed, the argument goes, magicians will just invent another illusion —indeed, a better one. Harry Kellar best illustrated this response one evening after a show. One of his illusions used an expensive, carefully-crafted trick box, and a member of the audience had indicated that he knew how the box worked. Kellar proceeded to take the box into an ally behind the theatre and chop it up with an axe. He told his assistants, "Now we'll build a new one that no one will figure out." 40 Yet, inventing new illusions is costly and difficult. It is no wonder that this reaction to exposure tends to be expressed primarily by magic's most creative and innovative performers. The exposures tend to reveal "common magic" while those performers use mostly "proprietary magic" and have the means and wherewithal to invent more of it.

\footnotetext{
${ }^{39}$ Jim Sisti, My Side of the Table: The Exposure Problem, GENII MAGAZINE 64, at 66 (Jan. 1998).

${ }^{40}$ STEINMEYER, supra note 27, at 168-69.
} 
The second argument for apathy relies on the unquestionable truth that secrets are "priceless and worthless at the same time." ${ }^{41}$ Secrets and tricks are only half of what makes a magician great. The other half is the presentation - the acting and staging that turn a mere trick into a captivating mystery, a puzzling illusion into a meaningful piece of performance art. Truth be told, many magicians grossly neglect this aspect of their craft, and this explains the existence of so many second-rate magicians. David Devant underscored the truth in a memorable exchange with an aspiring magician. He asked the aspirant how many tricks he knew, to which the aspirant boasted, "About three hundred." Devant, the world-famous old master, responded, "Actually, I know about eight myself."42 As he later explained, Devant was seeking to teach the young magician "the difference between knowing how a trick is done and knowing how to do it."43

Yet, the problem with this second argument is its fundamental confusion of what is necessary for magic with what is sufficient. While it remains true that good magic is more than a few secret tricks, magic would cease to be magic without those secrets. Robert-Houdin was right to think of himself as an "actor playing the part of a magician," but imagine how bad of an actor he would be if he could not fool his audience - that is, if he could not get his audience to believe his character, to believe that he was a magician. Magic has always grasped for respectability as a serious performing art, and de-emphasis of secrets surely flatters the artistic pretension. But magicians nevertheless depend on secrets as much as they depend on presentation, and apathy toward the former is just as dangerous as apathy toward the latter. And despite the naysayers, most magicians tend to agree.

Exposure has another harmful quality of particular relevance to intellectual property. One economic hesitance about treating ideas as property has focused on the notion that such

${ }^{41}$ Id. at 310.

${ }^{42} I d$. at 161 .

${ }^{43} I d$. 
intangible resources, unlike tangible property, tend to be "non-rival" and thus consumable at zero

marginal cost. ${ }^{44}$ Once a work of literature has been created, for example, everyone in the world can read it and enjoy it without depleting the literary resource. A piece of tangible property such as one's home, by contrast, does not have this quality. If Joe is using Bob's home, Bob cannot use it. Yet, although magic secrets are unquestionably an intangible resource, exposure of magic secrets does not have the non-rival characteristic that accompanies other uses of intangible resources. Exposure reveals the secret, and thereby destroys its value. R.J. Reynolds' or the masked magician's use of a secret is incompatible with the primary use of it by magicians. The revelation of an ordinary trade secret strips the secret-holder of his prior competitive advantage, but it does not preclude the original creator from continuing to use his innovative new process or gadget. Yet, not so with magic. Exposing a magic secret is more akin to burning down Bob's house - for the thrill and amusement of watching it burn.

\section{The Limits of Intellectual Property Law}

In our brief tour through the world of magic, we have seen how magicians benefit from sharing, but also how stealing and exposing present threats to the magic community. Magicians seek to maximize the amount of productive sharing within the magic community while minimizing the amount of stealing and exposure. We have also discovered an idiosyncratic kind of intangible resource- the magic secret-which defies the orthodox economic theory of intellectual property. In this Part, we examine the legal rules that presently secure rights to intellectual property, observing how those legal rules map onto magic's unique "innovation

\footnotetext{
44 "Ideas and information can . . . be used by many without depleting the enjoyment of others. . . [Intellectual property rights] therefore may allow the intellectual property owner to raise the price of that work above the marginal cost of producing it.” Robert P. Merges et al., InTEllectual Property in the New TeChnOlogical AGE 11-13 (3d ed. 2003).
} 
ecology." We will see that the law fails to protect magic's most valuable intellectual property, and that traditional IP law forces magicians to make undesirable tradeoffs that they would rather avoid.

\section{A. Copyright}

The first place we might look for intellectual property rights in magic is copyright law. The federal Copyright Act of 1976 affords copyright protection to original "dramatic works" and "choreographic works." ${ }^{45}$ These subject matter categories are surely capacious enough to accommodate magic acts. However, all copyright remains subject to the significant limitation that the original works be "fixed in [a] tangible medium of expression ... from which they can be perceived, reproduced, or otherwise communicated." ${ }^{46}$ This means that magicians can copyright scripts, written stage directions, or video recordings of their performances, and the copyrights could be used to block all substantially similar public performances of their copyrighted work. ${ }^{47}$ Importantly, however, magicians cannot copyright their most frequent creative act-the live performance.

Yet, the more significant difficulty with copyright involves the fact that magic tricks themselves cannot be copyrighted. A magician could conceivably copyright the dramatic aspects of his show, and he could copyright a written description of the method behind an illusion, so that his written description of the method could not be precisely reproduced. But the magician could not copyright the method itself. The law excludes it emphatically: "In no case does copyright protection for an original work of authorship extend to any idea, procedure, process,

\footnotetext{
4517 U.S.C. $\S 102(a)(3)-(a)(4)$.

${ }^{46}$ Id. at $\S 102(a)$.

47 "[I]n the case of dramatic, and choreographic works," the copyright owner has an exclusive right "to perform the copyrighted work publicly." 17 U.S.C. § 106(4).
} 
system, method of operation, concept, principle, or discovery regardless of the form in which it is described, explained, illustrated, or embodied in such work." ${ }^{48}$ Copyright law thus fails to protect the most common expression of magicians' intellectual property-live stage performance — as well as magicians' most valuable creations - the modus operandi behind each illusion.

B. Patent

One reason why ideas and methods do not receive copyright protection is the fact that such protection is thought to be available through patent law. Nineteenth century magicians often thought of their craft as a sort of scientific invention, and the patenting of new illusions enjoyed a brief period of popularity. Quickly, however, magicians discovered a most bothersome problem with patent law: To earn patent protection for their methods, magicians would have to reveal them. And that would defeat much of the point.

Maskelyne learned this lesson after securing a patent for an illusion of his called "Psycho." It consisted of a mysterious mechanical automaton, which appeared to think, answer questions, and act like a real human being. It became an instant hit in the theatres of London, but a writer soon discovered the patent and exposed Maskelyne's method to laymen by publishing it in McMillain's Magazine. Similarly, one of the thirty-nine illusions exposed by R.J. Reynolds in its tobacco ads was the famous "sawing a lady in half" trick, the exposed version of which was invented by American magician Horace Goldin. Outraged by the exposure, Goldin sued R.J. Reynolds alleging "unfair competition," but the court quickly dismissed his suit. Observing that Goldin had patented his illusion, the court explained:

${ }^{48} 17$ U.S.C. § 102(b). 
Certainly [Goldin's patent] is a clear and detailed expose of the secret to the public by the plaintiff himself. Any one who cares to can rightfully and lawfully procure a copy of said patent, containing a full detailed and diagramed explanation of the trick ... ${ }^{49}$

And, it should be added, any cigarette company can then publish that explanation in the newspapers for all to see.

Some nineteenth century magicians might have tried to obscure their secrets by offering vague descriptions in their patent papers. Describing their innovative method of using mirrors to make "ghosts" appear, Henry Dirks and J.H. Pepper explained unhelpfully, "The proper angle of inclination of the glass is ascertained experimentally . . .."50 Under modern patent law, however, this sort of ruse would not be worth the effort, as it would render the patent unenforceable. Federal patent law's stringent "written description" and "enabling disclosure" rules require "a written description of the invention, and of the manner and process of making and using it, in such full, clear, concise, and exact terms as to enable any person skilled in the art to which it pertains ... to make and use" the invention. ${ }^{51}$ Hence, in order for magicians to protect their intellectual property through patent law, they must make their secrets available to the public. They must thus be willing to destroy much of what makes that property valuable. Consequently, few magicians now patent their innovations. ${ }^{52}$

\section{Trade Secret}

\footnotetext{
${ }^{49}$ Goldin v. R.J. Reynolds Tobacco Co., 22 F. Supp. 61, 64 (S.D.N.Y. 1938).

50 STEINMEYER, supra note 20, at 37. Steinmeyer, who has reproduced the ghost illusion, calls the Dirks and Pepper description "all wrong." He adds, "For an optical effect like Pepper's ghost, the angles and sightlines of the audience's vision can be carefully calculated." Id. Curiously, Dirks and Pepper left those calculations out.

5135 U.S.C. $\$ 112$.

52 But see, e.g., John Gaughan, Levitation Apparatus, U.S. Patent No. 5,354,238, Oct. 11, 1994 (patenting a levitation illusion designed by John Gaughan but famously performed by David Copperfield). Gaughan reportedly filed the patent against Copperfield's wishes.
} 
Finally, we come to what some might suppose to be the most promising area of intellectual property law for magicians. Magic secrets, after all, are secrets; so perhaps trade secret law offers valuable legal protection. As with copyright and patent, however, trade secret law erects significant obstacles which greatly limit its value to the magic community. Horace Goldin, the magician who unsuccessfully sued R.J. Reynolds in 1938, did successfully use trade secret law in 1922 to block a film company from exposing his "sawing a lady in half" illusion. In a very broad ruling, the court granted Goldin's "unfair competition" claim and held that the film company had "unlawfully and unfairly take[n] advantage of the success which has rewarded the plaintiff's initiative." ${ }^{, 53}$ Although methods for the sawing illusion were publicly available and although the film company planned to expose a method that differed from Goldin's in significant ways, the court observed that "the conclusion cannot be escaped that the purpose of the defendants in the making and exhibition of their picture" was to deprive Goldin of his ability to perform the sawing illusion. ${ }^{54}$

Where Goldin triumphed, however, today's magicians are likely to fail. Modern trade secret law, despite variations from state to state, tends to take a far narrower view of trade secret protection than the 1922 court. Two particular requirements for trade secret protection present obstacles. First, trade secret law holds that liability for violating a trade secret only attaches to those violators who obtain the secret through "improper means." the breach of a "duty to maintain secrecy." $" 56$ Such duties can be created through contract, as well as implied in fact. Although the notion of improper means is quite malleable, ${ }^{57}$ Harry Kellar's

\footnotetext{
${ }^{53}$ Goldin v. Clarion Photoplays, Inc., 202 A.D. 1, 4 (N.Y. App. Div. 1922).

${ }^{54}$ Id. at 3-4.

${ }_{56}^{55}$ See Uniform Trade Secrets Act $\S 1(1)(1985)$.

${ }^{56} \mathrm{Id}$.

57 See RESTATEMENT OF TORTS $\S 757$, cmt. f, at 10 (1939) ("In general [improper means] are means which fall below the generally accepted standards of commercial morality and reasonable conduct.").
} 
bribery and espionage would likely have qualified as improper means, whereas the discovery of deKolta's secret flower design on the theatre floor probably would not have qualified. A former assistant could not breach a confidentiality agreement or an implied duty of confidentiality by sharing that secret with a rival magician. And in this limited respect, magicians have successfully used trade secret law in an effort to protect some of their proprietary magic from theft or exposure by former assistants. ${ }^{58}$

Yet, one common means of stealing and exposure does not require breaching any such duty of confidentiality. It instead involves discovering an illusion's method on one's own, and then copying or exposing it. The Decremps exposures, as well as many of the R.J. Reynolds exposures, resulted from what trade secret law calls "reverse engineering." The exposed secrets would thus not receive trade secret protection. As the Restatement puts it, "Independent discovery and analysis of publicly available products or information are not improper means of acquisition. ${ }^{, 59}$ Even if the use of the discovered secret is destructive to that piece of intellectual property, trade secret law does not prevent further exposure.

The second, and more significant, obstacle to trade secret protection for magicians is the law's requirement that secret-holders make "reasonable efforts to maintain secrecy." ${ }^{\circ 0}$ Indeed, the "essential characteristic of a trade secret [is] . . secrecy." ${ }^{, 61}$ And trade secret law tends to consider something no longer secret once it has been disclosed within an industry. Courts

\footnotetext{
${ }^{58}$ For example, David Copperfield requires those involved with his shows to sign the following agreement: I . . . understand that in the course of my employment I may become entrusted with the secrets of the illusions and magic in the David Copperfield Show. I realize that this is privileged information and that a great deal of time, energy, and money has been spent in the development of these illusions. I promise never to discuss these secrets and methods with any other person, relative or friend. The secrets of the Magic of David Copperfield are the proprietary rights of David Copperfield and under penalty of sever fine I agree to cooperate with my total secrecy.

David Copperfield, Secrecy Agreement (1998) (copy on file with author).

${ }^{59}$ RESTATEMENT (THIRD) OF UNFAIR COMPETITION $§ 43$.

${ }^{60}$ See Uniform Trade Secrets Act $\$ 1$ (4)(ii) (1985).

${ }^{61}$ J.T. Healy \& Son, Inc. v. James A. Murphy \& Son, Inc., 260 N.E. 2d 723, 730 (Mass. 1970).
} 
consider "the extent to which the information is known outside of [the secret-holder's] business" and the "ease or difficulty with which the information could be properly acquired or duplicated by others. ${ }^{, 62}$ If a method has been published in magicians' trade journals or books, or even if it has been shared informally among a number of magicians, it likely loses its entitlement to trade secret protection. Moreover, it does not matter whether the secret is disclosed by the secretholder, or by anyone else. ${ }^{63}$

Since so many secrets have been published and shared with other magicians, it remains very difficult for magicians to use trade secret law to prevent exposures. In response to the Fox Network's "masked magician" specials, the magic community tried to sue the network for violation of trade secrets. One magician, Andre Kole, alleged that Fox was exposing an illusion of his called the "Table of Death." The suit failed, however, after it was discovered that a similar trick, called the "Death of Cora," dated back to 1898 and had been published in several magic books. ${ }^{64} \mathrm{~A}$ similar class action suit by a group of magicians seeking to vindicate their "collective" right to magicians' trade secrets also failed. ${ }^{65}$ The fundamental difficulty with trade secret law rests on the fact that courts tend to view intellectual property as inhering in individuals or in firms, but not in industries. This stems from the traditional conception of trade secret law as a means of incentivizing innovators by giving them a competitive advantage over their direct competitors in the industry. Yet, the magic community's "innovation ecology" works differently. The threat of exposure results primarily from competition by industry outsiders, not by insiders.

\footnotetext{
${ }^{62}$ RESTATEMENT OF TORTS $§ 757, \mathrm{cmt} . \mathrm{b}$ (1939)

${ }^{63}$ See, e.g., Religious Technology Center v. Lerma, 908 F. Supp. 1362 (E.D. Va. 1995) (rejecting Church of Scientology's claim to trade secret protection for confidential scriptures, where scriptures were posted on the internet).

${ }_{65}^{64}$ Andre Kole v. Nash Entertainment, No. BC190153 (Cal. Sup. Ct. 1998).

${ }^{65}$ Harrison v. SF Broadcasting, 1998 WL 355462 (E.D. La.).
} 
Disclosure of secrets to insiders-i.e., to fellow magicians - thus does not void the intention to keep something secret. ${ }^{66}$

Nevertheless, despite this reality, hesitance to apply trade secret protections to magicians' common trade secrets may be understandable. It would be difficult to define who qualifies as an insider and who qualifies as an outsider for purposes of judging efforts to maintain secrecy. It would also be difficult to determine who speaks for the magic community in determining how different sorts of intellectual property should be used. Magicians themselves are often the ones who "sell out" and cause the most damaging exposures. Often, the industry outsider has an inside man. Hence, in sum, modern trade secret law forces magicians to choose between sharing a secret with their fellow magicians on the one hand, and preventing exposure to the lay public on the other. Trade secret law does not permit magicians to secure the benefits of sharing without bearing the costs of exposure. For "proprietary magic," trade secret law can be effective, since this kind of magic is not widely shared among magicians. But for the larger mass of "common magic," magicians are unable to use trade secret law to protect the most valuable aspect of their intellectual property—-their secrets.

\section{Intellectual Property Without Law}

As we have seen, neither copyright, patent, nor trade secret law offers significant protection for magicians' intellectual property. Many of IP law's qualifications and limitations flow from the assumption that intangible property is non-rival, and therefore that intellectual property holders should get something less robust than a full-fledged property right. Yet, IP law's partial property rights ill-suit the unique characteristics of magic secrets, which require

${ }^{66}$ Cf. Religious Technology Center v. Netcom On-Line Com., 923 F. Supp. 1231, 1254 n.25 (N.D. Ca. 1995) (Church of Scientology's distribution of scriptures to church members does not negate trade secret protection against disclosure to non-members.). 
more protection than intellectual property law can spare to afford. Copyright law might prevent some stealing of magic routines, but it cannot prevent stealing or exposure of magic methods; patent law can prevent stealing of magic methods, but it cannot prevent exposure of them; finally, trade secret law might prevent some stealing and exposure of "proprietary magic," but it cannot prevent the exposure of "common magic" without chilling the salutary practice of sharing among magicians.

Most magicians have come to understand this reality. Reflecting on his unsuccessful lawsuit against the Fox Network, Andre Kole recalled, "I felt somewhat like shooting a BB gun at a battleship." ${ }^{, 67}$ And one writer in Magic magazine observed bluntly, "The bottom line is that the legal system offers considerable potential for loss, with very little hope for victory."68

The lack of protection from intellectual property law, however, has not stopped magicians from innovating and thriving. Intellectual property law leaves the most damaging threat to magic - exposure - undeterred. Yet, despite a few high profile incidents, the magic community's intellectual property has not been subject to constant exposure. In this Part, we discover how magicians manage to create and enforce intellectual property rights without the help of formal intellectual property law. In short, the magic community has developed a fairly effective informal, norm-based IP regime which limits access, establishes use and exposure norms, and enforces violations - all outside the purview of the law.

\section{A. Controlling Access: Magic as a Common-Pool Resource}

The vast collection of shared "common magic" can be understood in one sense as a common-pool resource ("CPR"). Elinor Ostrom pioneered the study of CPRs in the context of

${ }^{67}$ Andre Kole: In His Words, MAGiC MAGAZINE 36, 39 (May 1998).

${ }^{68}$ Stan Allen, What Do We Do Now?, MagiC MagaZine 56, 60 (Feb. 1998). 
natural resource policy. Ostrom discovered a variety of organic, informal institutions that governed CPRs in the absence of both private property rights and central, top-down authority. She found "self-governing forms of collective action" which enabled "groups of principals [to] organize themselves voluntarily to retain the residuals of their own efforts." ${ }^{69}$ Yet, the ability of informal institutions to effectively govern CPRs depends first and foremost on "defining the boundaries of the CPR and closing it to "outsiders." ",70 And accordingly, the magic community controls access to its common intellectual resources quite artfully.

"Popular magic" remains easy to find. Anyone can go to the library to learn it or walk into the local magic shop to purchase it. This gives the false impression that the magic community does a poor job of controlling access to its secrets. In fact, however, the easy availability of "popular magic" brilliantly achieves what magicians call "misdirection." "Popular magic" serves to satisfy those in search of the cheap secret. And "popular magic" gives them just that - cheap secrets. These secrets are harmless in the hands of the general public, since they tend not to compromise the more valuable secrets that magicians aim to preserve. Moreover, "popular magic" plays an important filtering role. Many magicians will tell a familiar story of how they found their way into magic. They hung around the magic shop, voraciously absorbed all of the "popular magic" they could get their hands on, and made their dedication to the craft known. In time, they were noticed by more senior magicians, who deemed them worthy and offered them keys to the kingdom — the vibrant world of free-flowing "common magic."

For much of this "common magic," no real key is needed. New magicians only need advice on where to look. Yet, "popular magic" effectively diverts and filters in a way that manages to shield "common magic" from merely curious prying eyes. Magic magazines cannot

${ }^{69}$ Elinor Ostrom, Governing the Commons: The Evolution of Institutions for Collective Action 25 (1990).

${ }^{70} I d$. at 91 . 
be purchased at a newsstand, real magic books cannot be found at Barnes \& Nobles, and most "common magic" sits below the magic shop counter on top of which "popular magic" is displayed. Less subtle barriers also control access to many "common magic" resources. Membership in the International Brotherhood of Magicians, for instance, requires applicants to have been interested in magic for at least two years prior to admission and to secure sponsorship by two current members. Hollywood's Magic Castle club and London's Magic Circle club require applicants to audition for membership. Even Prince Charles, an amateur magic enthusiast, was made to audition before the Magic Circle would offer him membership.

"Proprietary magic" remains even more difficult to access. At this level, access is far less formal and granted on a more ad hoc basis. One must impress magic's top practitioners and earn their trust and respect. The most common way magicians earn such esteem is by winning the many national and international magic competitions organized by various groups each year. These resemble a kind of magicians' Olympic circuit, with contests in a variety of categories and awards of varying prestige. The highest honor for a magician is to win the FISM Grand Prix award bestowed by the Fédération Internationale des Sociétés Magiques ("FISM"), a United Nations-style international organization for the magic community. The competition occurs every three years, requires three endorsements to compete, and involves two grueling rounds of competition. The winner, chosen by a panel of judges, joins magic's most elite club of which only four Americans are members.

B. Attribution, Use, and Exposure Norms 
As magicians spend more time in the magic community, they come to internalize a handful of common norms that govern how secrets, techniques, and presentations are to be treated. ${ }^{71}$ The first category of norms deals with attributing credit to innovators and inventors:

(1) The first person to publish or prominently perform a trick gets credit for inventing it.

(2) People are encouraged to publish improvements and new versions of previously shared work, but derivative works should acknowledge and credit the original.

These norms function to encourage innovation and sharing. Considerable prestige attaches to the inventors and "teachers" of the magic community. Magicians are encouraged to publish books, give instructional lectures, and sell apparatus, in addition to simply performing their shows. Sharing is not expected to be done for free, and magicians can make a consideration amount of money teaching and supplying their ideas to other magicians. The attribution norms thus also advance the purposes of trademark law, since they help a magician build her reputation for producing quality work.

The second set of norms governs the use of a new idea once it has been created. Here, there are at least four major use norms:

(1) If a secret method or dramatic presentation has not been widely shared, published, or sold, nobody else can use it.

(2) If a secret method has been widely shared, published, or sold, it may be used freely.

\footnotetext{
${ }^{71}$ Although many of these rules are codified in various codes of ethics, this section draws heavily on my own experience and observations as a member of the magic community.
} 
(3) If a dramatic presentation has been widely shared, published, or sold, it may be used, but using it will be considered bad form.

(4) If a trick was originally published or shared but has not been used for a long time, the person who re-discovers it should be treated as if she invented it.

These norms encourage innovation by giving inventors the choice of whether to perform their inventions exclusively, or instead to gain the money and prestige associated with sharing those inventions. The norms frown upon stealing, while encouraging sharing. They also affirm the importance of originality in presentation and performance, both to spur magicians to take their craft seriously as an art as well as to protect magicians' trademarks among lay audiences. These use norms also encourage magicians to rediscover long forgotten tricks.

The third and final category of norms governs the exposure of the magic community's secrets to the lay public:

(1) Never expose a secret to a non-magician.

(2) Never expose a secret to a non-magician.

(3) Never expose a secret to a non-magician.

The message here is fairly clear, and this no-exposure norm remains the most strongly and consistently enforced of the bunch. Indeed, it tends to be treated as an absolute, per se rule. Magicians break the norm even when they reveal their own secrets. Any exposure damages the common enterprise of magic; it cheapens the craft.

The rights secured by this set of intellectual property norms overlap with those secured by formal intellectual property law. But they also differ in important respects. Magicians' IP norms tend to surround the common-pool resource of magic secrets with much taller fences than IP law, but the norms erect shorter fences than IP law to police the boundaries inside the 
common resource. While copyright law does not put any limits on using the ideas and methods contained in a copyrighted work, magicians' attribution norms create a right to be recognized. Magicians' use norms also protect live performances, as well as those fixed in a tangible medium. In fact, these norms may reverse copyright's preference for a tangible medium, since the norms tend to dissolve the creator's exclusive right once an idea has been published in tangible form. Performance of a trick without publishing it is a magician's strongest signal to the magic community that she intends to keep it for herself. In another respect, however, magicians' norms offer less protection than copyright law. Unlike copyright law, magicians' use norms do not give inventors exclusive performance rights to their published works. This is a significant difference that enables sharing within the magic community. Finally, and most obviously, magicians' exposure norms prohibit exposure of magic secrets to the general public, regardless of who invents the secret, how it is acquired, or with whom it was previously shared. This collection of intellectual property norms serves the magic community much better than the lawbased alternative. The norm-based IP regime protects against harmful exposure while enabling and encouraging productive innovation and sharing.

\section{Enforcement}

Of course, these norms would be of little value if they could not adequately be enforced. Although the magic community certainly endures its share of breaches, magicians tend to enforce norm-based IP rules reasonably well. All of the major magicians' organizations have well-established and respected codes of ethics. More informally, one's adherence to the attribution and use norms affects one's standing in the highly interconnected magic community. Those who violate the norms lose the respect of their peers. And such esteem counts for much. 
Hence, those who rise to prominence in the magic community tend to be exemplars of these norms, and thus help perpetuate the norms by modeling good behavior for all to see. Magicians who behave badly may not be invited to give lectures, perform in magic competitions, or be featured in magic trade publications.

Rogue manufacturers of magic tricks may be more difficult to control than performers and inventors with professional reputations to maintain. Yet, the magic community has done a reasonably good job of controlling manufacturers as well. One magician recalls his experience dealing with a manufacturer who stole one of his inventions:

[A] company in England, Illusions Plus, was selling still another rip-off of my illusion. When I protested to the owner, James Antony, he told me there was no court in the world which could stop him from what he was doing. I explained I had no intention of going to court. I instead simply told my many friends in [London's] Magic Circle about it $\cdots$

When the word spread, soon Mr. Antony 'had a problem.' As things turned out, there was indeed a court which promptly put him out of business...the bankruptcy court. $^{72}$

When a similar rogue manufacturer began selling a number of unauthorized illusions, a long list of magic's most respected leaders signed a letter shaming the manufacturer and asking it to cease and desist. Magic trade publications also tend to avoid publishing advertisements by disreputable manufacturers.

Although magicians seriously enforce their attribution and use norms, they save their most potent firepower for those in the magic community who violate the sacred exposure norm. The norm becomes instilled in a magician's consciousness from an early age, and violations are

\footnotetext{
${ }^{72}$ Open Letter from Walter Zaney Blaney to the Magic Community, Nov., 2002 (on file with author).
} 
punished swiftly and mercilessly. A few examples will suffice. David Devant, one of magic's greatest and most respected vaudeville performers, published a book entitled Secrets of My Magic in 1932. Having fallen into dire financial straits, Devant marketed the book to the lay public, and the title page declared Devant's intention to "disclose[] for the first time the Secrets of some of the Greatest Illusions of this Master of the Art of Magic." ${ }^{, 73}$ Although most of the exposed secrets were Devant's own, London's Magic Circle investigated Devant for violating the prestigious club's rules. This was no small matter, since Devant had helped found the club a few decades earlier, had been the club's first president, and had donated his library to it. But it did not matter. The Council of the Magic Circle voted to revoke Devant's membership, explaining, "We are extremely sorry for Mr. Devant . . . but surely . . the high, almost unique position attained by him in the world of magic [cannot] be any excuse." ${ }^{, 74}$ The Council added, "[I]f the Rules are to mean anything at all, no other decision could have been reached.",75

But what of magic's most notorious recent exposer-Fox's "masked magician?" The magic community discovered the identity of the masked magician shortly after his first television special, and well before he dramatically "revealed" his identity on the fourth special. The masked magician turned out to be a middling Las Vegas magician by the name of Val Valentino. One of Valentino's magician friends, after discovering that Valentino was the masked magician, recalled that he advised Valentino to go on TV and "do a Jimmy Swaggart thing, cry and ask for forgiveness. ${ }^{, 76}$ Valentino resisted, and was branded by magicians as the "masked traitor." ${ }^{, 77}$ Las Vegas illusion manufacturer Bill Smith vowed never to build another prop for Valentino. Although Valentino had been a magician for twenty-five years, nearly every one of his peers

\footnotetext{
${ }^{73}$ DAVID DeVANT, SeCRETS OF My Magic (1932).

${ }_{75}^{74}$ STEINMEYER, supra note 20, at 307.

${ }^{75} \mathrm{Id}$.

${ }^{76}$ Brownfield, supra note 37.

${ }^{77}$ Andre Kole: In His Own Words, supra note 67, at 37.
} 
shunned him from the community. "I'm sort of excommunicated now from the magic fraternity's world," Valentino admitted. ${ }^{78}$ And indeed he was. Shamed and disgraced in America, he fled to Brazil.

Indeed, magicians even enforce their anti-exposure norm against laypeople. Magician and collector Sidney Radner had loaned his multi-million dollar collection of Houdini artifacts to the Houdini Museum in Houdini's childhood home of Appleton, Wisconsin. Indeed, he even included a provision in his will that would have given the collection to the museum after his death. Yet, when the museum featured an exhibit revealing the secret to Houdini's Metamorphosis illusion, Radner reacted with outrage. He promptly took back his 1,000-piece collection and auctioned it off to various magicians. ${ }^{79}$ In a similar vein, the attorney who defended the Fox Network's exposure specials against the lawsuit by Andre Kole, confessed, "[O]ne of my partners who doubles as a professional magician stopped talking to me.",

\section{Conclusion: Lessons for Intellectual Property Theory}

This paper has pulled back the curtain on the world of magic — revealing the "innovation ecology" that animates the magic industry, outlining the inability of intellectual property law to mesh with magic's innovation dynamics, and yet explaining magic's innovation by way of a comparatively superior norm-based IP regime which has bloomed in law's absence. We may now take a step back to consider what IP scholars might learn from this study of the magic community.

\footnotetext{
${ }^{78}$ Brownfield, supra note 37.

${ }^{79}$ See Dean E. Murphy, In Sadness, Prime Houdini Artifact Collector Puts Items on Auction Block, N.Y. TIMES, Oct. 29, 2004.

${ }^{80}$ Jeffrey S. Kravitz, Do You Believe in Magic? Intellectual Property Protection for Reality TV Shows, INSIGHTS 5, 5 (Jan. 2003).
} 
The first lesson involves the role of exceptionalism in intellectual property theory. Scholars have wondered whether the presence of innovation in IP's various "negative spaces" owes itself to an overarching dynamic present in all of these negative spaces, or instead whether each space has its own unique dynamic that determines its particular innovation idiosyncrasies. ${ }^{81}$ In this clash between hedgehogs and foxes, the example of the magic industry supports the foxes. ${ }^{82}$ As we have seen, magic secrets involve a unique kind of intellectual property, indeed one that belies the traditional assumption that intangible property must be non-rival. Since the resource of magic secrets can actually be depleted by misuse, the need to protect such intellectual property takes on particular importance. The magic community's efforts to safeguard their intellectual property have thus been molded around this idiosyncratic imperative. At the same time, the magic community has sought to encourage another particular aspect of its innovation culture-sharing.

Neither orthodox IP law nor the total absence of IP rights could achieve these dual goals of preventing exposure and encouraging sharing. In either regime, the goals would be mutually exclusive. Hence, the second lesson we can glean from this study involves the power of norms, buttressed by organic relationships and self-organizing institutions, to create alternative IP regimes that enforce unique, industry-specific IP rights. Norms, rather than law, can be the source of much IP creativity. This norm-based explanation also suggests that not all of IP's successful negative spaces offer evidence that IP is unnecessary. As we have seen here, IP is extremely necessary in the magic industry, so necessary in fact that IP law has been jettisoned in

\footnotetext{
${ }^{81}$ See Chris Sprigman, The Negative Space of Copyright, University of Chicago Law Faculty Blog, Nov. 15, 2006, http://uchicagolaw.typepad.com/faculty/2006/11/the_negative_sp.html ("Is there a thread that links these (and other) fields in an integrated theory of innovation law? Or is each field subject to . . . socio-economic investigation ... ?").

${ }^{82}$ Cf. Isaiah Berlin, The Hedgehog and the Fox, in IsAiAh Berlin, The Proper Study OF MANkind: An ANTHOLOGY OF ESSAYS 436 (1997) ("The fox knows many things, but the hedgehog knows one big thing.").
} 
favor of IP norms. Hence, while the nature of the IP right has changed, the need for that right has not.

Yet, this brings us to our third lesson, and here we observe the potential fragility of normbased IP regimes. Norms may not always be a reliable savior to the woes of law. Consider the magic community's imperative of controlling access to its common pool of magic secrets. Without controlling access, the magic community would be vulnerable to outsiders who could misappropriate secrets without being subject to the magic community's norms. But the easy and growing availability of information on the internet makes it harder to control access than ever before. Wikipedia, for example, already explains the secrets to numerous tricks. Jon Racherbaumer, one of magic's old-timers fears the worst:

We live in a time of unprecedented access to knowledge and almost everyone promiscuously promulgates info-junk—-so-called facts, seductive factoids, spill-your-guts revelations, behind-the-scene scoops, titillating tabloid disclosures, tell-all biographies and autobiographies, and hard-nose investigative exposes... We are awash in wholesale exposure of every pedigree. ${ }^{83}$

The stable, norm-based IP equilibrium in the magic community could well unravel at some point in the future. Norms may thus not necessarily be a reason to quit worrying about law-based IP protections.

Finally, our fourth lesson suggests that courts ought to be more willing to heed the role of norms and idiosyncrasies in the application of IP law. Although a court would likely deem a piece of "common magic" shared among the magic community to be insufficiently deserving of trade secret protection, perhaps attention to norms suggests otherwise. To determine whether a secret has been sufficiently guarded, courts could look to the norms of the magic community

${ }^{83}$ Allen, supra note 68 , at 58. 
instead of relying on an ill-fitting paradigm of intra-industry competition. Doing so would suggest that, for magicians, revealing a secret to the community of fellow magicians is actually no revelation at all. The more significant revelation comes only when magic secrets are revealed in an accessible way to the general public. Property law has been solicitous of efficient norms in the past, and it might profit from aligning itself with norms again here. ${ }^{84}$

Until then, however, magicians will continue to innovate, continue to saw assistants in half, and continue to conjure their mysteries. They will continue to perform the cups and balls trick, preserved yet perfected since the days of Alciphron the Athenian. And magic's informal system of intellectual property will continue to make this possible, hidden as it may be, behind the curtain.

${ }^{84}$ Cf., e.g., Ghen v. Rich, 8 F. 159 (D. Mass. 1881) (adopting and affirming local norm that determined how whale fishermen identified rights of possession in caught whales). 